ISSN = 1980-993X - doi:10.4136/1980-993X
www.ambi-agua.net
E-mail: ambi-agua@agro.unitau.br
Tel.: (12) 3625-4212

\title{
Kinetics and mass transfer of atrazine ozonation (doi:10.4136/ambi-agua.132)
}

\author{
Rafaela Cristina Landeiro da Silva ${ }^{1}$; Roberto José de Carvalho ${ }^{2}$; Bruno Abreu Calfa ${ }^{3}$ \\ Departamento de Engenharia de Materiais - PUC-Rio \\ E-mail: ${ }^{1}$ rafaelalandeiro@yahoo.com.br; ${ }^{2}$ rjcar@puc-rio.br; ${ }^{3}$ bacalfa@gmail.com
}

\begin{abstract}
The kinetics of the atrazine oxidation in aqueous solution by ozone was studied under different initial $\mathrm{pH}$ conditions and in the presence of a hydroxyl radical scavenger at $\mathrm{pH} 2.8$. It was verified that the process took place mainly through radical reaction, even in acid medium. Therefore, a relatively high value of $26.4 \mathrm{~L} /(\mathrm{mol} . \mathrm{s})$ for the rate constant of the direct reaction between molecular ozone and atrazine was found. After 10 minutes of oxidation, the degradation of the herbicide was more effective for $\mathrm{pH} 10.30$ than for $\mathrm{pHs} 6.25$ and 2.80. The mass transfer of ozone from the gas phase to the liquid phase was strongly affected by the oxygen flowrate and to a lesser extent by the stirring speed.
\end{abstract}

Keywords: atrazine; ozonation; kinetics; mass transfer.

\section{Cinética e transferência de massa da ozonização da atrazina}

\section{RESUMO}

A cinética da oxidação da atrazina em solução aquosa por ozônio foi estudada sob diferentes condições de $\mathrm{pH}$ inicial e na presença de um sequestrador do radical hidroxila em pH 2,8. Verificou-se que o processo ocorreu principalmente através da reação com o radical, mesmo em meio ácido. Portanto, um valor relativamente elevado de 26,4 L/(mol.s) para a constante cinética da reação direta entre o ozônio molecular e atrazina foi encontrado. Após 10 minutos de oxidação, a degradação do herbicida foi mais efetiva para $\mathrm{pH}$ 10,30 do que para pHs 6,25 e 2,80. A transferência de massa do ozônio da fase gasosa para a fase líquida foi fortemente afetada pela vazão de oxigênio e, em menor medida, pela velocidade de agitação.

Palavras-chave: atrazina; ozonização; cinética; transferência de massa.

\section{INTRODUCTION}

The growing demand for agricultural products has driven the use of large amounts of pesticides to prevent or combat pests and ensure higher productivity (Sanches et al., 2003). Due to their indiscriminate use, pesticides have been detected in surface and groundwaters throughout the world. Thus, it is necessary to develop technologies that promote the degradation of these pollutants. A promising alternative is the application of an oxidative process using ozone as the oxidizing agent (ozonation).

Among the pesticides systematically monitored in the water bodies, atrazine (2-chloro-4ethylamino-6-isopropylamine-s-triazine) emerges as the most frequent and abundant (Sousa, 2002). Atrazine is a selective herbicide used in the control of weeds, especially in crops of maize, sugar cane and sorghum (Sanches et al., 2003). Studies have indicated that atrazine is resistant to biological degradation (Adams and Randtke, 1992). Therefore, several authors have studied different methods for degradation of this herbicide. The processes for water treatment include: i) physical processes such as adsorption and extraction; ii) biological processes; iii) chemical processes such as chlorination and advanced oxidation. In general, 
adsorption and extraction are cost effective and easy to perform. However, they only allow the transfer of the pollutant to another phase, not promoting its degradation to a less harmful species (Belhateche, 1995).

A promising way to enable degradation of an undesired chemical species is to apply oxidative treatments employing various agents such as ozone $\left(\mathrm{O}_{3}\right)$, hydrogen peroxide $\left(\mathrm{H}_{2} \mathrm{O}_{2}\right)$, UV (Meunier et al., 2006), combinations of oxidizing agents such as $\mathrm{O}_{3} / \mathrm{H}_{2} \mathrm{O}_{2}, \mathrm{O}_{3} / \mathrm{UV}$, or the use of Fenton reagent and photo-Fenton system (Huston and Pignatello, 1999).

Ozone is an excellent oxidizing agent and has become attractive for the treatment of drinking water and wastewater, due to its low generation cost and high oxidizing potential $\left(\mathrm{E}^{0}\right.$ $=2.07 \mathrm{~V}$ ). It can promote the degradation of various organic pollutants in a short time (Kunz et al., 1999). The use of ozonation as a technique for wastewater treatment is still very limited in emerging countries like Brazil, because it requires a large amount of investments. However, in several developed countries the ozonation technology is widely used in water purification, especially for the production of drinking water.

The ozonation of atrazine in water has been studied by different authors (Adams et al., 1990; Yao and Haag, 1991; Adams and Randtke, 1992; Xiong and Graham, 1992; Beltrán et al., 1994, Acero et al., 2000) to identify the main by-products formed and determine the kinetic rate constant of the overall reaction between ozone and this herbicide. However, the reported results show a great discrepancy in the values found for this parameter.

In this work, the kinetics of the ozonation of soluble atrazine was studied at different $\mathrm{pHs}$ and in the presence of a hydroxyl radicals scavenger. A kinetic equation is proposed representing the oxidation of atrazine by molecular ozone. The mass transfer of ozone from the gas phase to the liquid phase was also investigated by evaluating the influence of several experimental parameters such as the inlet gas flow and the solution stirring speed.

\section{MATERIALS AND METHODS}

\subsection{Chemicals}

Oxygen gas (99.5\%) was used for ozone generation. Atrazine degradation tests were performed using commercial atrazine (Gesaprim 500) purchased from Sigma Aldrich Química Brasil Ltda. Mixtures of methanol (HPLC grade) and water (distilled-deionized) were used as the mobile phase in HPLC experiments. Solutions of sodium hydroxide $(0.01$ $\mathrm{mol} / \mathrm{L})$ and sulfuric acid $(0.06 \mathrm{~mol} / \mathrm{L})$, purchased from Vetec Química Fina Ltda., were used to adjust the initial pHs. All stock solutions were prepared with distilled-deionized water. All chemicals were used as received without further purification.

\subsection{Equipments}

All experiments were performed in a cylindrical glass reactor $(32 \mathrm{~cm}$ high and $4 \mathrm{~cm}$ internal diameter). The ozone was produced by an Ozontechik generator with a throughput of $80 \mathrm{mg} / \mathrm{h}$. The experimental setup is shown in Figure 1. Atrazine concentration was measured by HPLC (Perkin Elmer Series 200, USA) equipped with an UV/VIS absorption detector. Quantification of ozone in solution was performed in a model Spec 20MV spectrophotometer. The efficiency of atrazine ozonation was evaluated by determining the total organic carbon in a TOC analyzer (Shimadzu, Japan). 


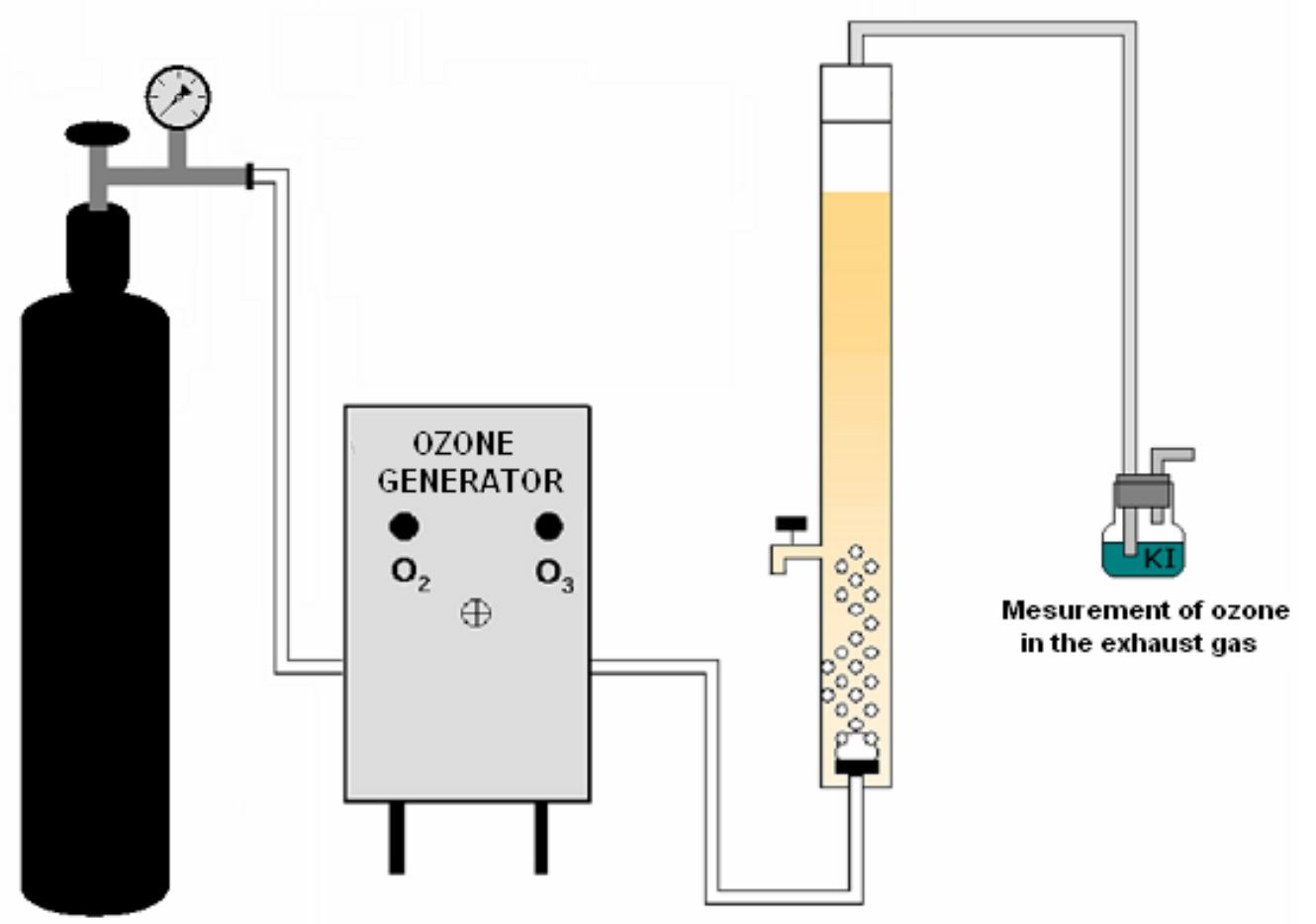

Figure 1. Atrazine ozonation setup.

\subsection{Procedures}

To prevent loss of material due to the agitation of the system during the injection of gas and to ensure better efficiency of the system, only $75 \%$ of the total reactor volume was used. The ozone was fed at the base of the reactor which was fitted with a porous bubble diffuser to improve mass transfer from the gas to the liquid phase. The excess of ozone was collected and washed in a KI solution to be quantified by iodometry.

For each of the experiments, a pre-determined volume of distilled and deionized water was saturated with a continuous ozone flow for 20 minutes. Solutions of sulfuric acid $(0.06 \mathrm{~mol} / \mathrm{L})$ or sodium hydroxide $(0.01 \mathrm{~mol} / \mathrm{L})$ were added to the ozone solution to adjust the $\mathrm{pH}$. The reaction was set off by adding $10 \mathrm{~mL}$ of a $0.3 \mathrm{mg} / \mathrm{mL}$ atrazine solution (Gesaprim 500) to the saturated ozone solution resulting in a final volume of $300 \mathrm{~mL}$.

Ozonation tests were conducted with the objective of determining the effect of $\mathrm{pH}$ and contact time on the rate of atrazine degradation. The values of $\mathrm{pH}$ utilized were 2.8, 6.3 and 10.3. To obtain the rate constant of the reaction between ozone and atrazine, $0.01 \mathrm{~mol} / \mathrm{L}$ of $\mathrm{t}$ butanol was added in the aqueous medium at $\mathrm{pH} 2.8$ in order to slow the reaction rate.

Samples with approximately $4 \mathrm{~mL}$ were collected at different times and residual atrazine was immediately analyzed in a Perkin Elmer Series 200 HPLC equipped with a UV/VIS detector. A Microsolb C18 column (150 mm length x $4.6 \mathrm{~mm}$ internal diameter, particle size $5 \mathrm{~nm}$ ) was used and an isocratic elution with mobile phase composed by a $65 \%$ in volume methanol solution at a flowrate of $0.5 \mathrm{~mL} / \mathrm{min}$ was performed for the separation of atrazine. The solvents were previously filtered in Millipore membrane filters and degassed offline in an ultrasound bath. The samples were filtered through $0.2 \mu \mathrm{m}$ pore membranes before the analysis. The volume injected was $20 \mu \mathrm{L}$. The wavelength used was $222 \mathrm{~nm}$ selected from the absorption spectrum of a standard atrazine solution with a concentration of $10 \mathrm{mg} / \mathrm{L}$.

The identification of atrazine in the samples was done by comparing its retention time with that of the standard solution. The calibration curve used for determining the atrazine concentrations was constructed using five concentrations of an atrazine standard with a purity of 95.4\%: 1.0; 2.5; 5.0; 7.5 and $10.0 \mathrm{mg} / \mathrm{L}$. For each standard concentration, three injections were made. Atrazine concentration was determined by interpolation in the calibration curve using simple linear regression. 
Atrazine degradation was evaluated by measuring the concentration of total organic carbon (TOC) according to the method described by Eaton et al. (1998). $20 \mathrm{~mL}$ samples were collected at the end of each ozonation test and analyzed.

Experiments for determining the mass transfer capacity coefficient were performed at $\mathrm{pH}$ 2.8. Aliquots of approximately $6 \mathrm{~mL}$ were taken throughout ozonation for the purpose of quantifying the ozone in solution using a colorimetric method with indigo as described by Eaton et al. (1998). Table 1 summarizes the conditions adopted in each of the tests.

Table 1. Test conditions for calculation of the mass transfer capacity coefficient.

\begin{tabular}{c|c}
\hline $\mathbf{O}_{\mathbf{2}}$ flowrate (L/h) & Stirrer rotational speed \\
\hline \multirow{2}{*}{12} & 0 \\
& 100 \\
& 155 \\
\hline \multirow{2}{*}{21} & 0 \\
& 100 \\
& 155 \\
\hline
\end{tabular}

\section{RESULTS AND DISCUSSION}

\subsection{Effect of Initial pH}

The effect of $\mathrm{pH}$ on the concentration of dissolved ozone is presented in Figure 2. The concentration increases in the first minutes until it reaches a stationary value. As in Sotelo et al. (1989), it is observed that the concentration of dissolved ozone decreases with increasing $\mathrm{pH}$ due to the higher concentration of $\mathrm{OH}^{-}$ions in basic medium, since these ions promote the decomposition of ozone. Higher concentrations of ozone are obtained in acid medium due to the lower concentrations of $\mathrm{OH}^{-}$ions available to decompose the ozone molecule.

The effect of initial $\mathrm{pH}$ on the efficiency of atrazine ozonation is shown in Figure 3. When the initial $\mathrm{pH}$ of the solution increased from 2.8 to 6.3 , there was a $24 \%$ increase in the degradation of atrazine after 10 minutes of ozonation. In this same time of treatment, $97 \%$ degradation was obtained when the initial $\mathrm{pH}$ of the solution was increased to 10.3 , which corresponded to an increase of approximately $47 \%$ when compared to the results obtained in acid medium. In acid medium, the ozone tends to react by the direct mechanism (oxidation by $\mathrm{O}_{3}$ ). At such condition, the degradation is usually less efficient. In basic medium, the ozone reacts with hydroxyl ions leading to formation of radical species, particularly hydroxyl radicals $(\mathrm{OH})$. Due to the non-selective nature of hydroxyl radicals, the indirect mechanism (oxidation by ${ }^{\circ} \mathrm{OH}$ ) is generally more efficient to degrade organic compounds. 
SILVA, R. C. L.; CARVALHO, R. J.; CALFA, B. A. Kinetics and mass transfer of atrazine ozonation. AmbiAgua, Taubaté, v. 5, n. 2, p. 9-20, 2010. (doi:10.4136/ambi-agua.132)

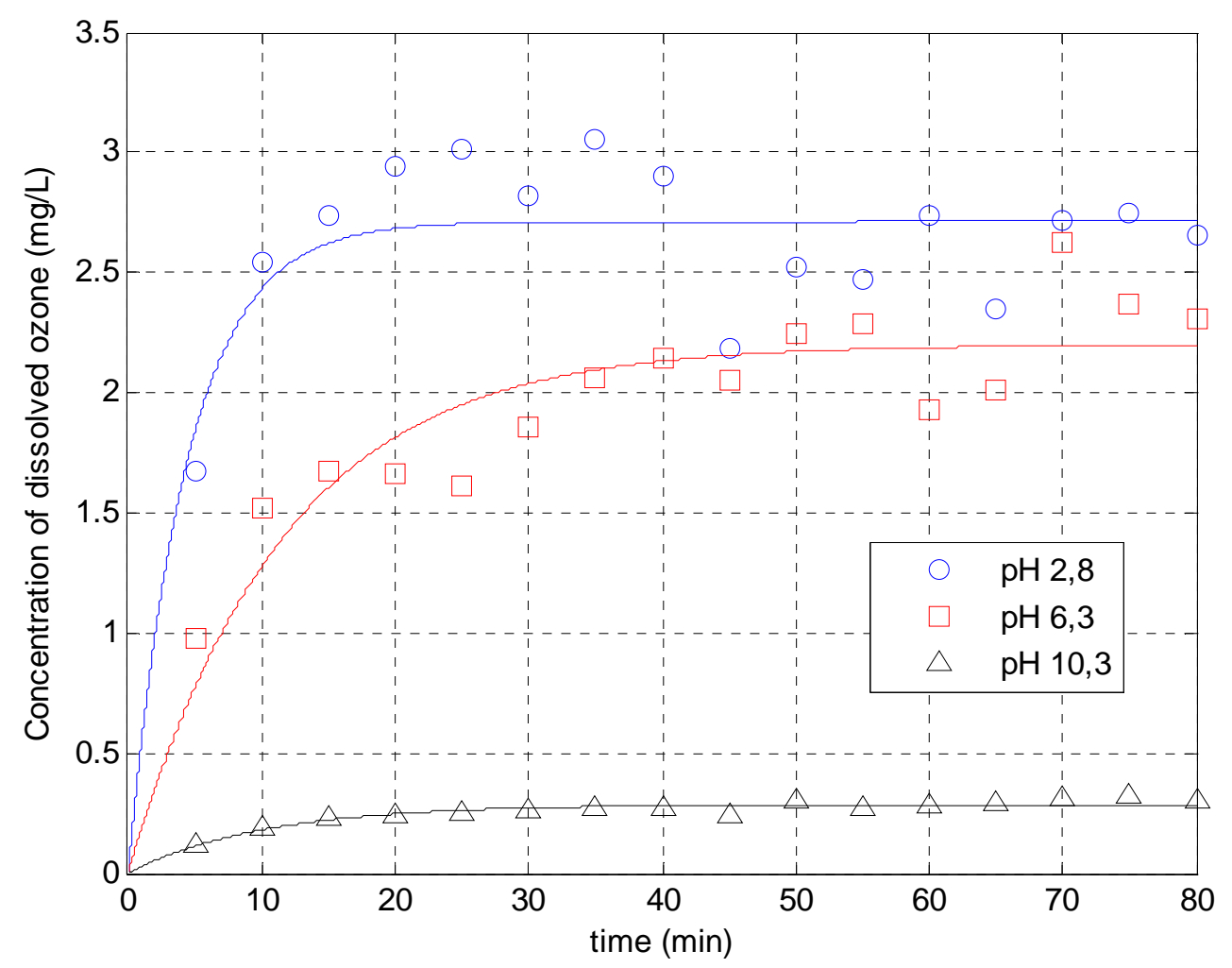

Figure 2. Effect of $\mathrm{pH}$ on dissolved ozone concentration $\left(\mathrm{O}_{2}\right.$ flowrate: $12 \mathrm{~L} / \mathrm{h}$; stirrer rotational speed: $100 \mathrm{rpm})$.

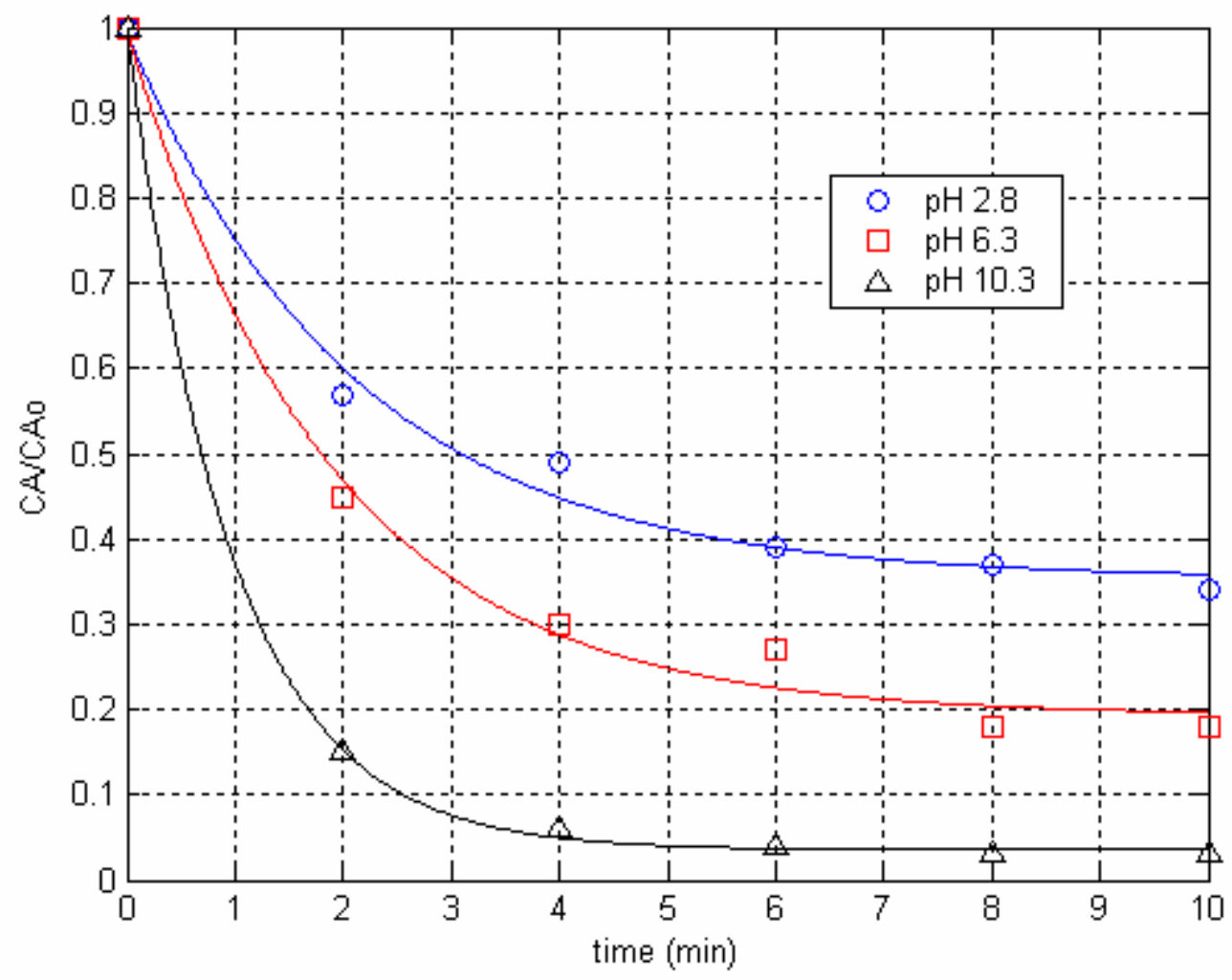

Figure 3. Effect of $\mathrm{pH}$ on atrazine degradation.

\subsection{Atrazine Mineralization}

Examining the total organic carbon content (TOC), there were mineralization rates of approximately $20 \%(\mathrm{pH}=2.8$ and $\mathrm{pH}=6.3)$ and $60 \%(\mathrm{pH}=10.3)$ in 10 minutes of ozonation. Despite the greater efficiency in the degradation of atrazine at $\mathrm{pH} 6.3(80 \%)$ than at $\mathrm{pH} 2.8$ (65\%), removal of TOC is the same in both cases. This result can be explained by the 
SILVA, R. C. L.; CARVALHO, R. J.; CALFA, B. A. Kinetics and mass transfer of atrazine ozonation. AmbiAgua, Taubaté, v. 5, n. 2, p. 9-20, 2010. (doi:10.4136/ambi-agua.132)

generation of by-products of atrazine ozonation. The by-products generated by exposure of atrazine to ozone for 10 minutes are illustrated in Figures 4 to 6 for a wavelength of $222 \mathrm{~nm}$.

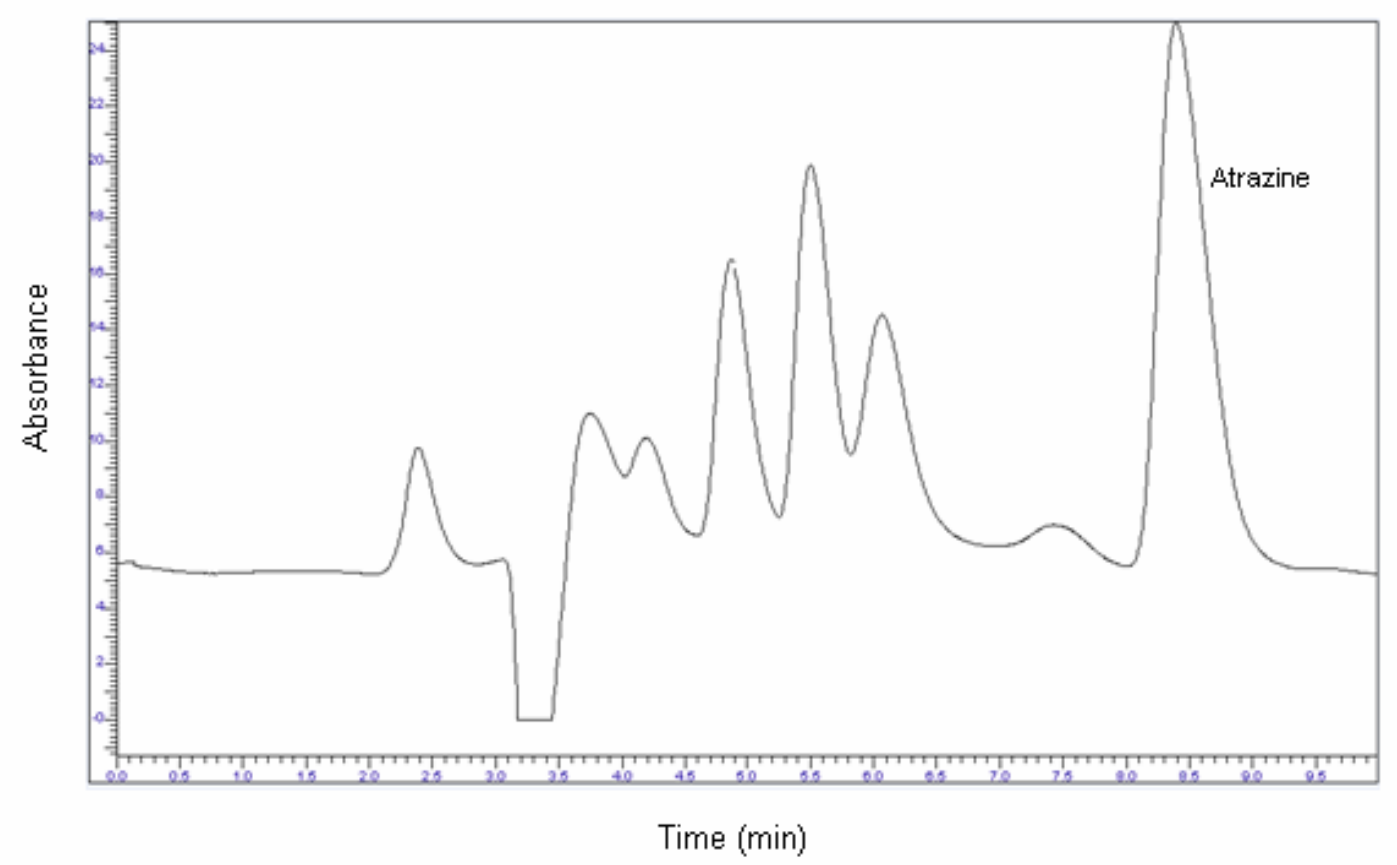

Figure 4. Chromatogram for atrazine ozonation at $\mathrm{pH} 2.8$ after 10 minutes.

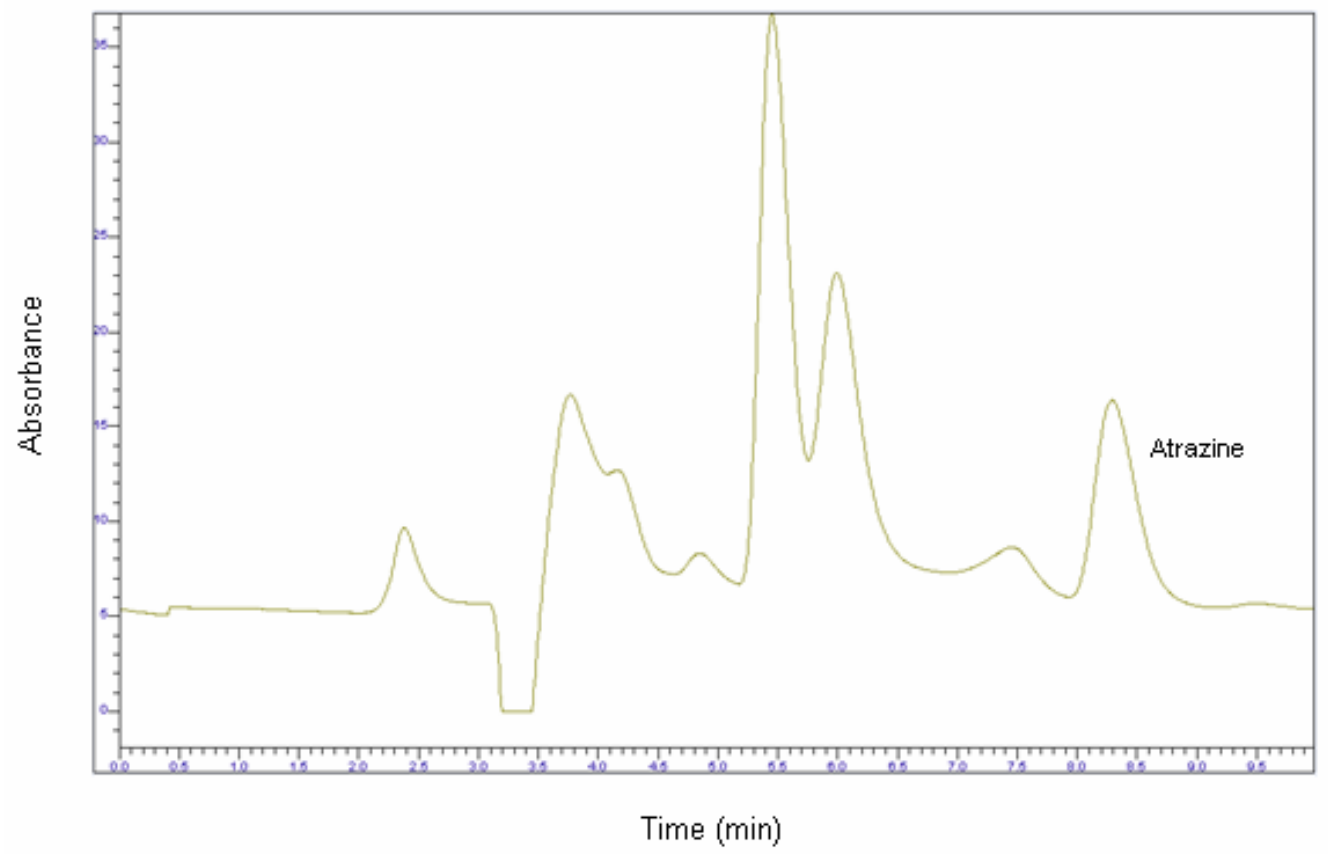

Figure 5. Chromatogram for atrazine ozonation at $\mathrm{pH} 6.3$ after 10 minutes. 


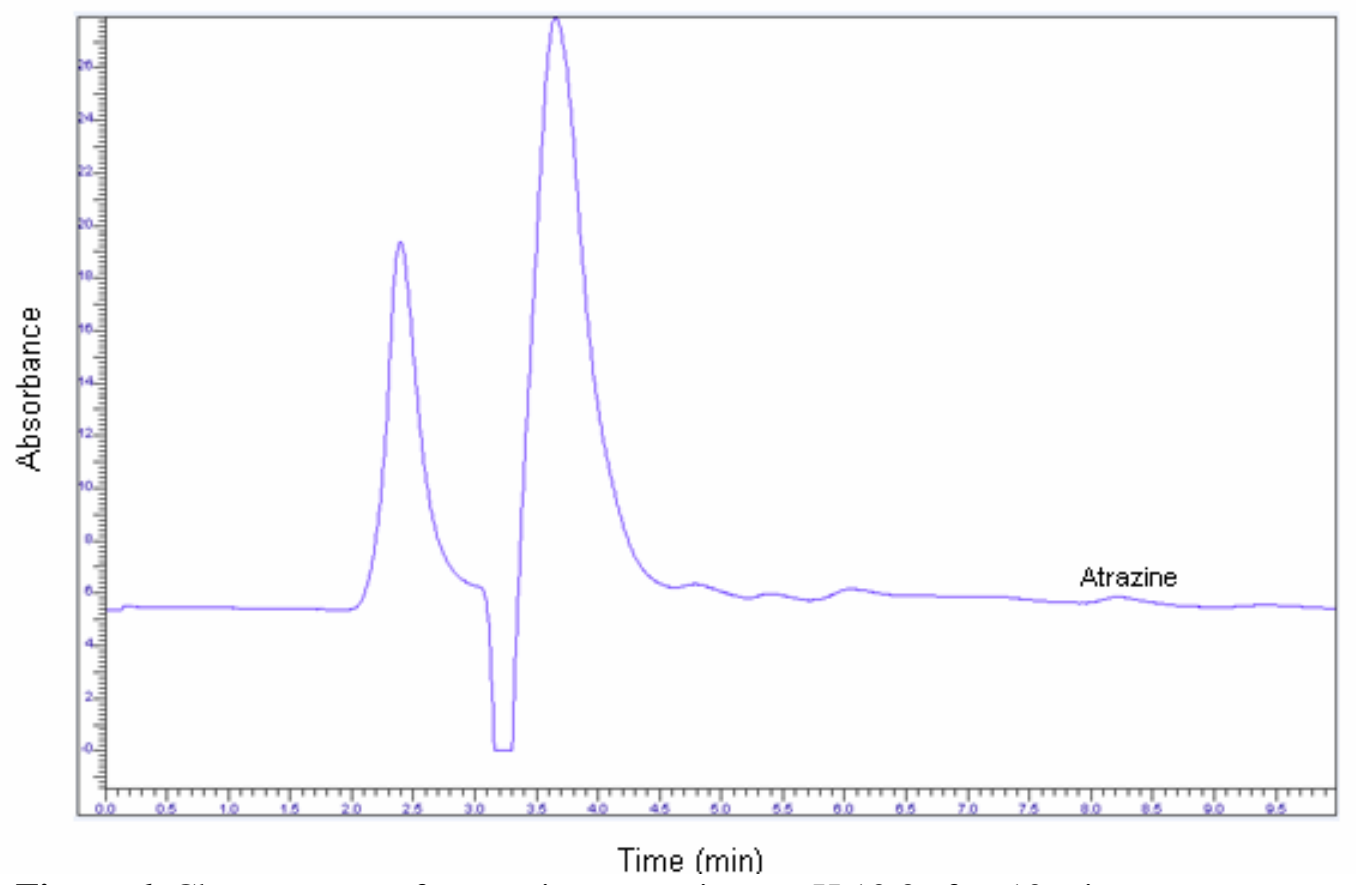

Figure 6. Chromatogram for atrazine ozonation at $\mathrm{pH} 10.3$ after 10 minutes.

\subsection{Atrazine Ozonation Kinetics}

The degradation of atrazine by direct ozonation is a complex process where both the oxidation of atrazine and the decomposition of dissolved ozone may take place due to its instability in aqueous media containing $\mathrm{OH}^{-}$anions. Atrazine is degraded through reaction with molecular ozone and $\mathrm{OH}$ radicals due to decomposition of dissolved ozone, according to Equations 1 and 2.

$$
\begin{aligned}
& \text { Atrazine }+\mathrm{O}_{3} \stackrel{k_{\mathrm{O}_{3}}}{\longrightarrow} \text { Products } 1 \\
& \text { Atrazine }+\cdot \mathrm{OH} \stackrel{k_{\cdot \mathrm{OH}}}{\longrightarrow} \text { Products } 2
\end{aligned}
$$

Thus, the rate of degradation in the ozonation process may be described by Equation 3 .

$$
-\frac{d C_{A}}{d t}=k_{O_{3}} C_{A} C_{O_{3}}+k \cdot{ }_{O H} C_{A} C_{\cdot O H}
$$

where $C_{A}$ is the atrazine concentration, $t$ is the reaction time, $k_{O_{3}}$ is the rate constant for reaction $1, k_{{ }_{\mathrm{OH}}}$ is the rate constant for Equation 2 and $C_{\cdot_{\mathrm{OH}}}$ is the concentration of hydroxyl radicals and $\mathrm{C}_{\mathrm{O}_{3}}$ is the concentration of dissolved ozone.

However, the rate of ozone decomposition depends on the $\mathrm{pH}$ value. In acid media, the rate of decomposition is very small and the contribution of Equation 2 can be neglected. Based on this fact, this work considers only the degradation of atrazine by direct ozonation, Equation 1, since the experiments were performed at $\mathrm{pH} 2.8$ and in the presence of t-butanol. The t-butanol decreases the action of hydroxyl radicals reacting rapidly with it. The rate constant for this reaction is $7.3 \times 10^{8} \mathrm{~L} /(\mathrm{mol} . \mathrm{s})$ (Hoigné and Bader, 1983).

Neglecting the reactions of intermediate products or by-products of ozonation, the atrazine degradation rate is simplified to:

$$
-\frac{d C_{A}}{d t}=k_{O_{3}} C_{A} C_{O_{3}}
$$


According to Beltrán et al. (1994), the concentration of ozone reaches a maximum and stationary value in the ozonation process. If Equation 4 is applied for a reaction time equal to or greater than that required for the ozone concentration reach its saturation value, $C_{O_{3}}^{\text {sat }}$, then the ozonation of atrazine follows a pseudo-first order kinetics:

$$
-\frac{d C_{A}}{d t}=k_{O_{3}}^{\prime} C_{A}
$$

where: $k_{O_{3}}^{\prime}=k_{O_{3}} C_{O_{3}}^{\text {sat }}$

The solution of Equation 5 is given by:

$$
C_{A}=C_{A o} e^{-k^{\prime}{ }_{0} t}
$$

where: $C_{A o}$ is the initial concentration of atrazine.

The variation of atrazine concentration with time for the experimental conditions indicated is presented in Figure 7. As seen in this figure, a good fit was obtained between the experimental concentrations and the concentrations predicted by Equation 7 (correlation coefficient 0.987 ).

The rate constant for the degradation of atrazine by molecular ozone was evaluated as $26.4 \mathrm{~L} /(\mathrm{mol} . \mathrm{s})$. Different values for the rate constant of the direct ozonation reaction were determined by other authors. Some results are listed in Table 2.

The difference between the rate constant obtained in this work and the values found in the literature may be imputed to the different experimental conditions used, especially the $\mathrm{pH}$ which is directly related to the concentration of hydroxyl radicals generated by the decomposition of ozone.

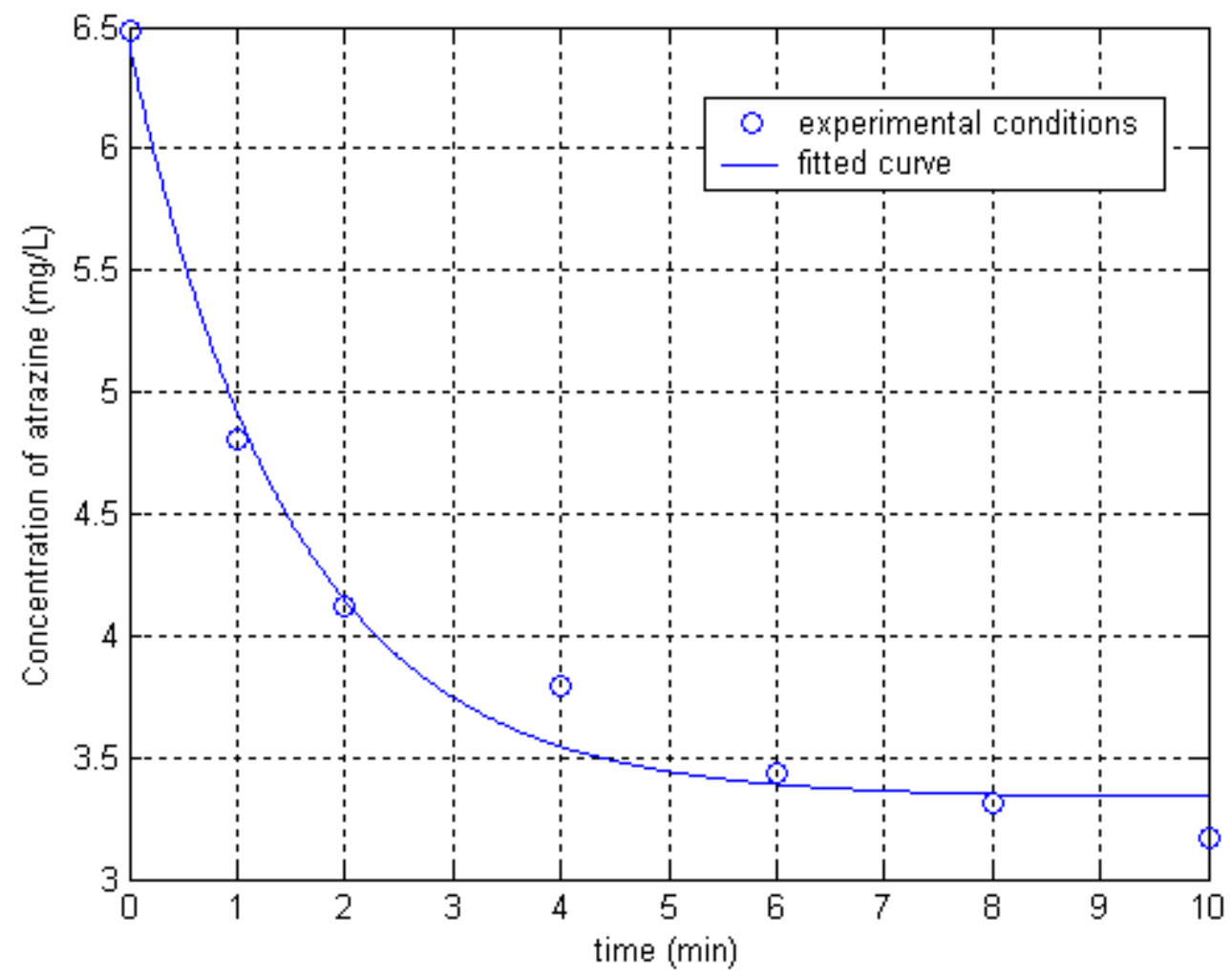

Figure 7. Variation of atrazine concentration with time $\left(\mathrm{O}_{2}\right.$ flowrate: $12 \mathrm{~L} / \mathrm{h}$; stirrer rotational speed: $100 \mathrm{rpm}$; temperature: $25^{\circ} \mathrm{C}$; $\mathrm{pH}$ : 2.8; $0.01 \mathrm{~mol} / \mathrm{L}$ t-butanol). 
Table 2. Rate constants for the direct reaction between ozone and atrazine presented in the literature.

\begin{tabular}{rrcl}
\hline $\mathbf{p H}$ & Rate constant, $k_{\mathrm{O}_{3}}$ (L/(mol.s)) & $\begin{array}{c}\text { OH sequestrant } \\
\text { concentration }\end{array}$ & Reference \\
\hline $7.5^{\mathrm{a}}$ & 12.24 & cabonate, $10^{-4} \mathrm{~mol} / \mathrm{L}$ & Xiong and Graham (1992) \\
$2^{\mathrm{a}}$ & 2.25 & t-butanol, $0.01 \mathrm{~mol} / \mathrm{L}$ & Xiong and Graham (1992) \\
$4.1^{\mathrm{b}}$ & 6 & t-butanol, 0.01 mol/L & Yao and Haag (1991) \\
7 & 6 & t-butanol, 0.02 mol/L & Acero et al. (2000) \\
2 & 4.5 & t-butanol, 0.05 mol/L & Beltrán et al. (1994) \\
$5^{\mathrm{b}}$ & $73^{\mathrm{c}}$ & -- & Adams et al. (1990) \\
$7^{\mathrm{b}}$ & $146^{\mathrm{c}}$ & -- & Adams et al. (1990) \\
$9^{\mathrm{b}}$ & $617^{\mathrm{c}}$ & -- & Adams et al. (1990) \\
$7^{\mathrm{d}}$ & $125^{\mathrm{c}}$ & -- & Adams and Randtke (1992) \\
2.8 & 26.4 & t-butanol, $0.01 \mathrm{~mol} / \mathrm{L}$ & this study \\
\hline
\end{tabular}

abatch competitive ozonation with MCPA (2-methyl-4-chlorophenoxyacetic acid) as reference. ${ }^{b}$ batch ozonation. ${ }^{\mathrm{C}}$ reported as total rate constant. ${ }^{\mathrm{d}}$ Continuous ozonation.

\subsection{Mass Transfer of Ozone}

The kinetics of the ozonation process is usually controlled by mass transfer of ozone from the gas phase to the liquid phase. Several models have been proposed to describe this transfer. Generally these models postulate that the concentration of ozone in both phases is homogeneous except in a thin layer around the gas-liquid interface.

The mass transfer capacity coefficient, $k_{L} a$, is determined from the mass balance in the liquid phase given by the following equation:

$$
\frac{d C_{O_{3}}}{d t}=k_{L} a\left(C_{O_{3}}^{s a t}-C_{O_{3}}\right)-k_{O_{3}} C_{O_{3}}
$$

The experimental runs were conducted at room temperature and $\mathrm{pH} 2.8$ with the purpose of minimizing ozone decomposition and thus eliminate $k_{O_{3}}$ in Equation 8. Under these conditions this equation can be integrated to:

$$
C_{O_{3}}=C_{O_{3}}^{s a t}\left[1-\exp \left(-k_{L} a t\right)\right]
$$

The variation of the dissolved ozone concentration with time for three stirring speeds $(0$ rpm, $100 \mathrm{rpm}$ and $155 \mathrm{rpm}$ ) is presented in Figure 8 for an $\mathrm{O}_{2}$ flowrate of $12 \mathrm{~L} / \mathrm{h}$ and in Figure 9 for an $\mathrm{O}_{2}$ flowrate of $21 \mathrm{~L} / \mathrm{h}$. It may be observed in these figures that with increasing stirring speed the dissolved ozone concentration reaches its maximum value in a shorter time.

The values of $C_{O_{3}}^{\text {sat }}, k_{L} a$ and $\mathrm{R}^{2}$ for different $\mathrm{O}_{2}$ flowrates and stirring speeds presented in Table 3 were obtained by fitting the data shown in Figure 8 and 9 with Equation 9. They are similar to those reported by Kunz et al. (1999) and Beltrán et al. (2000) and suggest a high mass transfer rate in the reactor. They also indicate that the gas flowrate and especially the stirring speed affect the mass transfer of ozone from the gas phase to the liquid phase. 
SILVA, R. C. L.; CARVALHO, R. J.; CALFA, B. A. Kinetics and mass transfer of atrazine ozonation. AmbiAgua, Taubaté, v. 5, n. 2, p. 9-20, 2010. (doi:10.4136/ambi-agua.132)

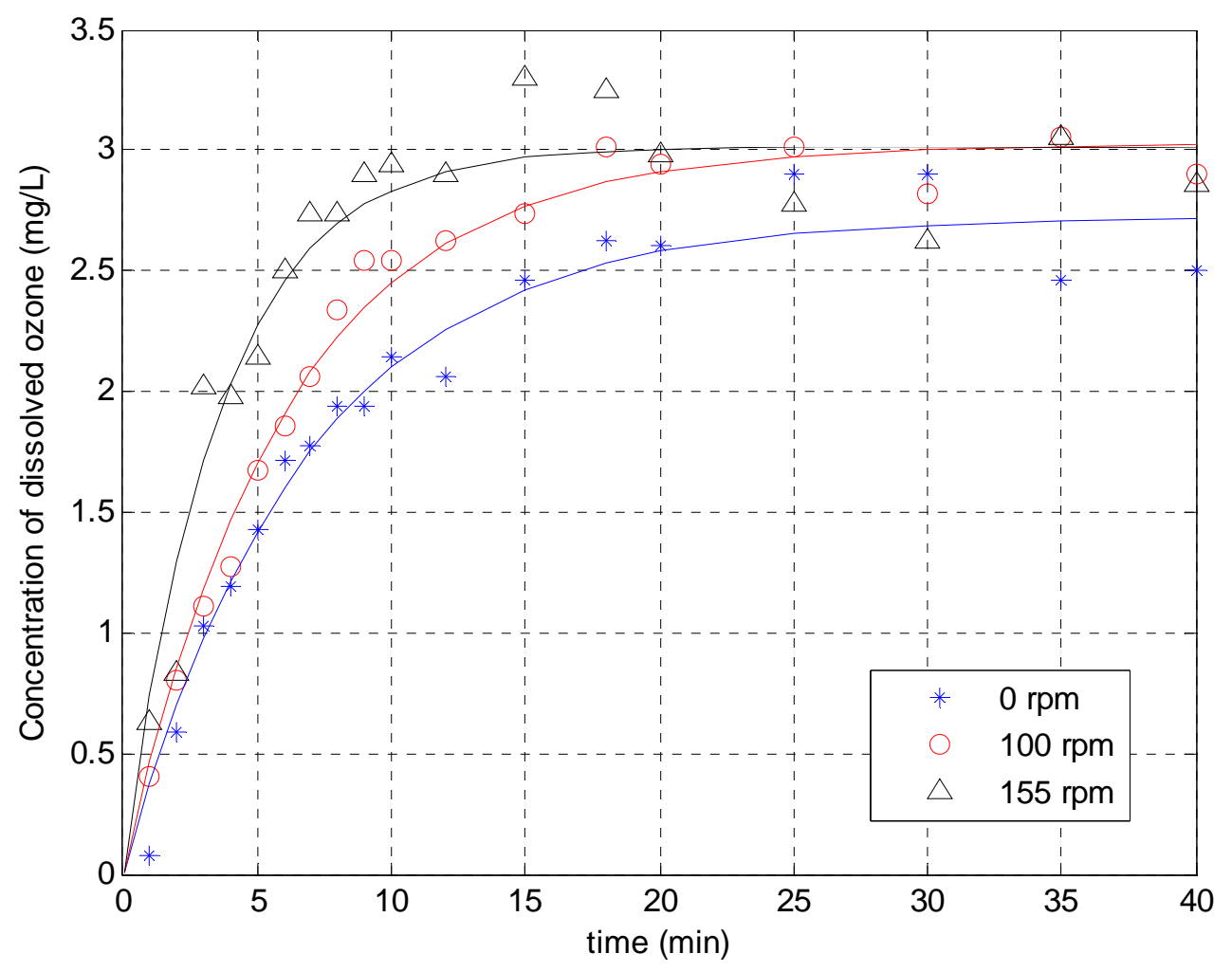

Figure 8. Variation of dissolved ozone concentration with time for an $\mathrm{O}_{2}$ flowrate of $12 \mathrm{~L} / \mathrm{h}, \mathrm{pH}=2.8$.

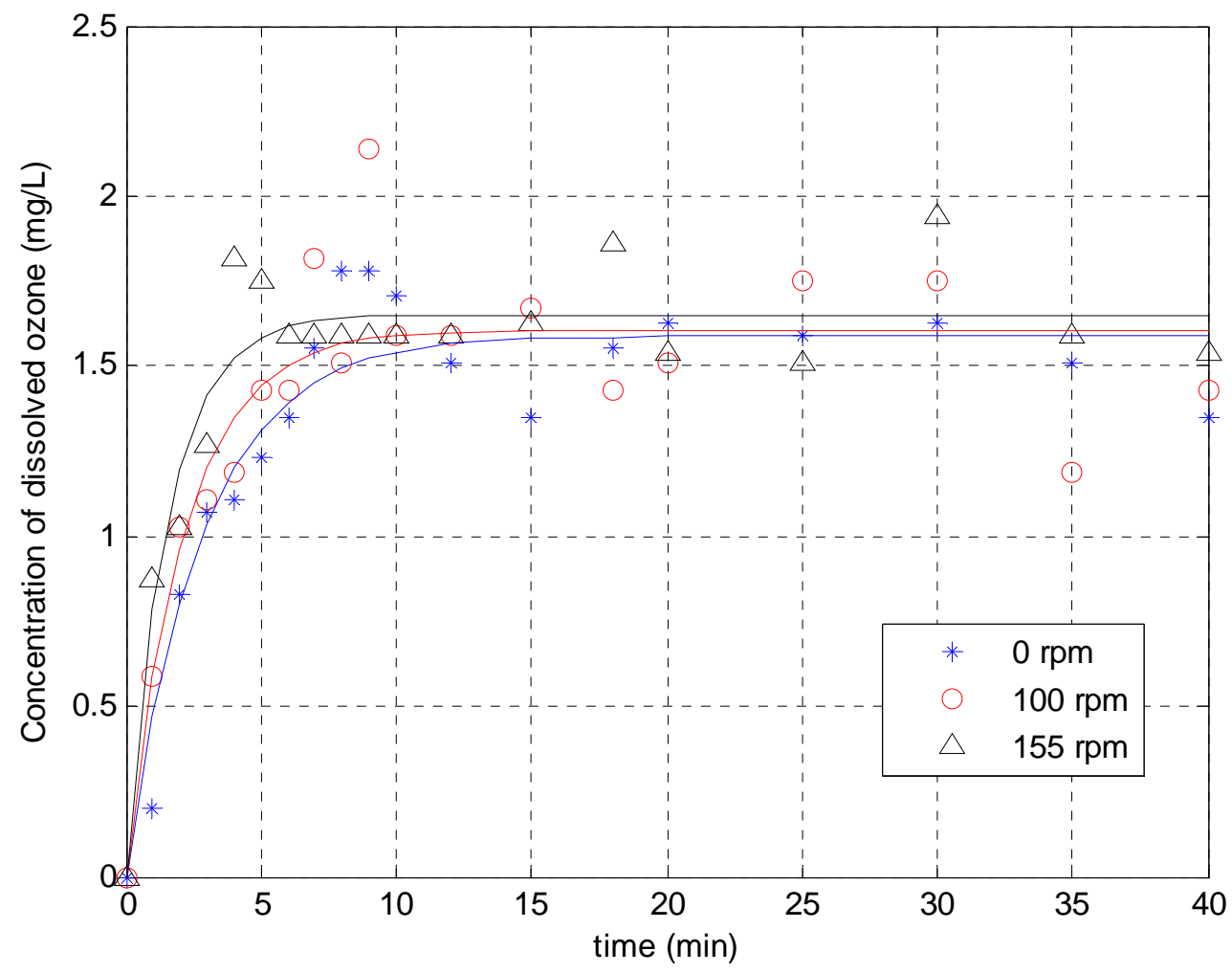

Figure 9. Variation of dissolved ozone concentration with time for an $\mathrm{O}_{2}$ flowrate of $21 \mathrm{~L} / \mathrm{h}, \mathrm{pH}=2.8$. 
Table 3. Mass transfer capacity coefficients, $k_{L} a\left(\min ^{-1}\right)$, for different stirring speed and oxygen flow rates.

\begin{tabular}{|c|c|c|c|c|c|c|}
\hline & \multicolumn{3}{|c|}{$\mathrm{O}_{2}$ flowrate (12 L/h) } & \multicolumn{3}{|c|}{$\mathrm{O}_{2}$ flowrate $(21 \mathrm{~L} / \mathrm{h})$} \\
\hline & 0 rpm & $100 \mathrm{rpm}$ & $155 \mathrm{rpm}$ & 0 rpm & $100 \mathrm{rpm}$ & $155 \mathrm{rpm}$ \\
\hline$C_{O_{3}}^{\text {sat }}$ & 2.722 & 3.023 & 3.016 & 1.589 & 1.607 & 1.650 \\
\hline$k_{L} a$ & 0.1477 & 0.1662 & 0.2810 & 0.3512 & 0.4571 & 0.6472 \\
\hline $\mathrm{R}^{2}$ & 0.9728 & 0.9887 & 0.9481 & 0.9076 & 0.8206 & 0.8961 \\
\hline
\end{tabular}

\section{CONCLUSIONS}

The $\mathrm{pH}$ had a pronounced effect on the concentration of dissolved ozone and determines the predominant oxidant $\left(\mathrm{O}_{3}\right.$ or $\left.\mathrm{OH}\right)$ for the reaction with atrazine. The process is carried out mainly through radical reaction, even in acid medium.

The rate constant of the direct reaction between molecular ozone and atrazine was 26.4 L/(mol.s).

The degradation of atrazine was more effective at $\mathrm{pH} 10.3$ than at $\mathrm{pHs} 6.3$ and 2.8.

The rate constant for the atrazine ozonation reaction determined in this work was relatively high when compared to the values found in the literature. This may have been caused by the different experimental conditions used, especially the $\mathrm{pH}$ which is directly related to the concentration of hydroxyl radicals generated by the decomposition of ozone set off by the $\mathrm{OH}^{-}$anions.

The transfer of ozone from the gas phase to the liquid phase was strongly affected by the oxygen flowrate and to a lesser extent by the stirring speed.

\section{ACKNOWLEDGEMENTS}

The authors are grateful to CNPq for supporting this research. Rafaela Cristina Landeiro da Silva thanks CNPq and FAPERJ for granting a M.Sc. scholarship.

\section{REFERENCES}

ACERO, J. L.; STEMMLER, K.; Von GUNTEN, U. Degradation kinetics of atrazine and its degradation products with ozone and $\mathrm{OH}$ radicals: a predictive tool for drinking water treatment. Environmental Science and Technology, Washington, v. 34, n. 4, p. 591597, 2000.

ADAMS, C. D.; RANDTKE, S. J.; THURMAN, M. E.; HULSEY, R. A. Occurrence and treatment of atrazine and its degradation products in drinking water. In : American Water Works Association Annual Conference, Cincinati, 1990. Proceedings... AWWA: Denver, 1990. p. 871-894.

ADAMS, C. D.; RANDTKE, S. J. Ozonation byproducts of atrazine in synthetic and natural waters. Environmental Science and Technology, Washington, v. 26, n. 11, p. 22182227, 1992.

BELHATECHE, D. H. Choose appropriate wastewater treatment technologies. Chemical Engineering Progress, New York, v. 91, n. 8, p. 32-51, 1995.

BELTRÁN, F. J.; GARCÍA-ARAYA, J. F.; ACEDO, B. Advanced oxidation of atrazine in water - I. Ozonation. Water Research, London, v. 28, n. 10, p. 2153-2164, 1994.

BELTRÁN, F. J.; GONZÁLEZ, M.; ACEDO, B.; RIVAS, F. J. Kinetic modelling of aqueous atrazine ozonation processes in a continuous flow bubble contactor. Journal of Hazardous Materials, Amsterdam, v. B80, p.189-206, 2000. 
EATON, A. D.; CLESCERI, L. S.; GREENBERG, A. E. Standard methods for the examination of water and wastewater. 20. ed. Washington: American Public Health Association: 1998. $1 \mathrm{v}$.

HOIGNÉ, J.; BADER, H. Rate constants of reactions of ozone with organic and inorganic compounds in water - I: Non-dissociating organic compounds. Water Research, London, v. 17, n. 2, p. 173-183, 1983. HUSTON, P. L.; PIGNATELLO, J. J. Degradation of selected pesticide active ingredients and commercial formulations in water by the photo-assisted Fenton reaction. Water Research, London, v. 33, n. 5, p. 1238-1246, 1999.

KUNZ, A.; FREIRE, R. S.; ROHWEDDER, J. J. R.; DURAN, N.; MANSILLA, H.; RODRIGUEZ, J. Construção e otimização de um sistema para produção e aplicação de ozônio em escala de laboratório. Química Nova, São Paulo, v. 22, n. 3, p. 425-428, 1999.

SANCHES, S. M.; SILVA, C. H. T. P.; CAMPOS, S. X.; VIEIRA, E. M. Pesticidas e seus respectivos riscos associados à contaminação da água. Pesticidas: Revista de Ecotoxicologia e Meio Ambiente, Curitiba, v. 13, p. 53-58, 2003.

MEUNIER, L.; CANONICA, S.; Von GUNTEN, U. Implications of sequential use of UV and ozone for drinking water quality. Water Research, London, v. 40, n. 9, p. 1864-1876, 2006.

SOTELO, J. L.; BELTRÁN, F. J.; BENITEZ, F. J.; BELTRÁN-HEREDIA, J. Henry’s law constant for the ozone-water system. Water Research, London, v. 23, n. 10, p.12391246, 1989.

SOUSA, I. J. Pesticidas: que estratégia de avaliação na água destinada ao consumo humano. Lisboa: Associação Portuguesa de Distribuição e Drenagem de Água - Comissão Especializada de Qualidade da Água, 2002.

XIONG, F.; GRAHAM N. J. D. Rate constants for herbicide degradation by ozone. Ozone: Science and Engineering, London, v. 14, n. 4, p. 283-301, 1992.

YAO C. C. D.; HAAG W. R. Rate constants for direct reactions of ozone with several drinking water contaminants. Water Research, London, v. 25, n. 7, p. 761-773, 1991. 